\title{
Some Properties of Asparagus Virus II Isolated from Asparagus officinalis in Japan
}

\author{
Ichiro Fujisawa*, Tadanori Goto*, Tsuneo Tsuchizaki** \\ and Norio IIzuk ** \\ 藤澤一郎*・後藤忠則*・土崎常男**・飯塚典男* : アスパラ \\ ガスから分離された asparagus virus II
}

\begin{abstract}
A virus was isolated from symptomless asparagus plants (Asparagus officinalis) in Hokkaido, Japan. The virus infected 28 plant species belonging to 8 families by sap inoculation. Artificially infected asparagus plants occasionally produced faint, light-green mosaic symptoms on the leaves. The virus was transmitted through seeds of infected plant of asparagus, tobacco, Zinnia elegans and Petunia hybrida, but not by aphids. Thermal inactivation point of the virus was between 55 and $60 \mathrm{C}$, dilution end point between $10^{-3}$ and $2 \times 10^{-4}$ and longevity in vitro was 2-3 days at $20 \mathrm{C}$. Purified virus preparation contained isometric particles with a diameter ranging from 26 to $36 \mathrm{~nm}$, and reacted positively with the antisera in immunodiffusion test against asparagus virus II described in the U.S. A.

On the basis of symptomatology, host range, mode of transmission, physical properties, particle morphology and serological relationships, the virus was identified as asparagus virus II.
\end{abstract}

(Received June 2, 1983)

Key Words : asparagus virus II, asparagus.

\section{Introduction}

The occurrence of asparagus virus II (AVII) was reported for the first time in Germany in 1964). AVII appeared to be identical with asparagus latent virus described later in Denmark ${ }^{6}$. AVII was also isolated in North America $^{5)}$, and reported to belong to the ilarvirus (isometric labile ringspot virus) group ${ }^{10)}$. In 1981 we have reported that two mechanically transmissible viruses were isolated from asparagus plants in Hokkaido ${ }^{2}$. The one was filamentous particles identified as asparagus virus $\mathrm{I}^{3)}$. The other virus was spherical particles and some of the properties including host range, physical properties, serological characteristics are described in the present report.

\footnotetext{
* Hokkaido National Agricultural Experiment Station, Hitsujigaoka, Toyohira-ku, Sapporo 061-01, Japan 農林水産省北海道農業試験場

** Institute for Plant Virus Research, Yatabe, Tsukuba, Ibaraki 305, Japan 農林水産省植物ウイ ルス研究所
} 


\section{Materials and methods}

Virus source. The virus used in this study was an isolate obtained from a symptomless asparagus plant (Asparagus officinalis) in Hokkaido and was tentatively designated as asparagus virus II-J (AVII-J). The virus was maintained with tobacco plants (Nicotiana tabacum 'Xanthi nc') and Chenopodium quinoa in a greenhouse. Mechanical inoculation was carried out as described previously ${ }^{3}$. Inoculated plants were kept under observation for 20 days and checked for the presence of the virus by back-inoculation to $C$. quinoa.

Serology. Antiserum against the virus was obtained by subjecting a rabbit to three intramuscular injections of $1 \mathrm{ml}$ of purified AVII-J emulsified with an equal volume of Freund's complete adjuvant at 3-weeks intervals. Blood was removed from the rabbit 3 weeks after the last injection. Antisera against AVII-P and AVII-S were kindly supplied by Dr. G. I. Mink, Washington State University, Prosser.

Electron microscopy. The purified virus was fixed with $10 \%$ formalin for 30 min and then stained with $2 \%$ phosphotungstic acid, $\mathrm{pH} 7.0$, and examined under a Hitachi H 12 electron microscope.

\section{Results}

\section{Occurrence and symptoms in asparagus}

From 1978 to 1981, asparagus leaves showing no definite symptoms were collected from various localities in Hokkaido and tested by inoculation to $C$. quinoa, tobacco (N. tabacum 'Xanthi nc') and Gomphrena globosa. Fifty-three of the 111 samples collected caused symptoms on the indicator plants, which resembled those induced by A VII-J, and one of the samples proved to be doubly infected with asparagus virus I (AVI) and AVII-J. In our survey of asparagus fields in Hokkaido, AVII-J was found to occur in almost all the fields. AVII-J failed to infect healthy asparagus seedlings after manual inoculation with the extract of infected tobacco or C. quinoa leaves. However, when the spears of asparagus were inoculated with concentrated purified AVII-J, asparagus became easily infected, and showed sometimes only faint, light-green mosaic symptoms about 20 days after inoculation (Plate I. 4). On the other hand, no such visible symptoms appeared on the leaves of newly-developed spears of manually inoculated asparagus plants as well as on those infected through seed. During the three years' observation of the seed-transmitted asparagus plants in the fields, some infected plants may be slightly less productive than healthy plants.

\section{Host range and symptomatology}

Forty-three herbaceous species belonging to 12 families were inoculated with the extracts of infected tobacco leaves. The virus was capable of infecting twenty-seven species in seven families (Table 1). Those plants such as $C$. quinoa, tobacco ( $N$. tabacum 'Xanthi nc'), G. globosa and Zinnia elegans developed characteristic symptoms, which made them suitable as assay plants for the detection of the virus. On $C$. quinoa, a few chlorotic spots were formed on the inoculated leaves 5 days after 
Table 1. Host range of asparagus virus II-J isolated from asparagus in Hokkaido, Japan

\begin{tabular}{ll} 
Plants susceptible & \\
Liliaceae & Asparagus officinalis \\
Chenopodiaceae & Chenopodium amaranticolor ${ }^{\mathrm{a}}$, C, quinoa, Beta vulgaris, B. vulgaris var. \\
& cicla, Spinacia oleracea. \\
Solanaceae & Nicotiana tabacum (Samsun, White Burley, Xanthi nc), N. glutinosa, N. \\
& clevelandii, Physalis floridana, Petunia hybrida, Lycopersicon esculentum, \\
& Capsicum frutescens, \\
Cucurbitaceae & Cucurbita pepo, Citrullus vulgaris ${ }^{\mathrm{a}}$, Cucumis sativus ${ }^{\mathrm{a}}$. \\
Amaranthaceae & Celosia cristata, Gomphrena globosa. \\
Leguminosae & Vicia faba ${ }^{\mathrm{a}}$, Vigna sesquipedalis ${ }^{\mathrm{a}}$, V. angularis, Glycine max, Phaseolus \\
Compositae & vulgaris, Pisum sativum ${ }^{\mathrm{a})}$. \\
Aizoaceae & Tetragonia expansa \\
Plants insusceptible & \\
Liliaceae & Lilium elegans, Allium fistrulosum, A cepa, A. tuberosum \\
Solanaceae & Datura stramonium, Solanum melongena \\
Cucurbitaceae & Cucumis melo \\
Amaranthaceae & Amaranthus retroflexus \\
Pedaliaceae & Seamum indicum \\
Compositae & Lactuca sativa \\
Umbelliferae & Daucus carota, Apium graveolens, Cryptotaenia canadensis \\
Cruciferae & Brassica rapa var. Komatsuna, B. rapa \\
Gramineae & Zea mays \\
\hline
\end{tabular}

a) local infection

inoculation, followed by severe systemic mosaic and epinasty (Plate I. 1). On tobacco, the virus induced necrotic ring lesions on the inoculated leaves 5-7 days after inoculation followed by systemic mottle with vein necrosis (Plate I. 2). On G. globosa, the virus induced large necrotic ring lesions on the inoculated leaves 7 days after inoculation followed by systemic mosaic with necrosis (Plate I. 3). On Z. elegans, the virus induced systemic mosaic symptoms and yellowing.

\section{Transmission}

Seeds collected from asparagus plants infected with AVII-J were germinated in the greenhouse, and the seedlings were assayed on C. amaranticolor. Of the 100 seedlings tested, 49 were infected with AVII-J. No symptoms developed in these infected plants maintained for a period of 12 months in the greenhouse. The virus was transmitted in $36 \%$ of the progeny of tobacco ( $N$. tabacum 'Samsun'), in $22 \%$ of that of Z. elegans and in $26 \%$ of that of Petunia hybrida. Tests of virus transmission by aphids, Myzus persicae, gave negative results irrespective of length of acquisition feeding periods.

\section{Properties in vitro}

Sap from infected tobacco ( $N$. tabacum 'Xanthi nc') leaves had a dilution end point ranging between $10^{-3}$ and $2 \times 10^{-4}$, when diluted with $0.1 \mathrm{M}$ phosphate buffer 
( $\mathrm{pH} 7.0$ ), and retained its infectivity for 2 to 3 days at $20 \mathrm{C}$. It was infective after heating for $10 \mathrm{~min}$ at $55 \mathrm{C}$ but not at $60 \mathrm{C}$.

\section{Virus particles}

Particles of AVII-J was purified according to modified procedure for peanut stunt virus $^{9}$. The purified virus preparation proved to be infective. In electron micrographs of the purified virus preparations, numerous isometric particles with various diameter ranging from $26 \mathrm{~nm}$ to $36 \mathrm{~nm}$ were observed (Plate I. 5).

\section{Serology}

Antiserum prepared against AVII-J had a homologous titer of 1/1024 in ring interface precipitin test, and formed a single line of precipitate with the virus. Serological relationships among AVII-J, AVII-P and AVII-S were determined by immunodiffusion test. AVII-J reacted positively with both antisera against AVII-P (Plate I. 6 a) and AVII-S (Plate I. $6 \mathrm{~b}$ ). A spur was formed when it was tested against antisera to AVII-J and AVII-P, but not against antisera to AVII-J and AVII-S.

\section{Discussion}

Several spherical viruses, AVII ${ }^{4,5,6,9)}$, tobacco streak virus ${ }^{1,5)}$, cucumber mosaic virus $^{8)}$, tomato black ring virus ${ }^{7)}$, arabis mosaic virus ${ }^{7)}$ and strawberry latent ring spot virus ${ }^{7)}$ have so far been isolated from asparagus. The characteristics of host range, symptomatology, physical properties and seed-transmission of the virus were similar to those of AVII described by Uyeda and Mink ${ }^{10)}$. Two serotypes of AVII such as AVII-P and AVII-S were reported in the U.S. A.. Our isolate reacted with both antisera against AVII-P and AVII-S in agar gel double diffusion tests. However, a spur with AVII-J was formed when AVII-J was tested against antisera to AVII-J and AVII-P but not against antisera to AVII-J and AVII-S. On the basis of these results, AVII-J reported here was serologically more closely related to AVII-S than AVII-P. AVII has been reported to be composed of four viral components, and each component alone was noninfectious ${ }^{10)}$. Further studies are in progress to determine the similar results could be obtained from our isolate.

Uyeda and Mink $^{10)}$ reported that AVII failed to infect asparagus seedlings by manual inoculation. In our experiment, however, when the spears of asparagus were inoculated with concentrated purified virus, asparagus plants became easily infected, and showed sometimes mosaic symptoms. Since it is the first time that AVII-J has been identified in Japan, the economic importance of this virus in asparagus plants is as yet unknown.

\section{Literature cited}

1. Brunt. A. A. and Paludan, N. (1970). Phytopathol. Z. 69: 277-282.

2. Fujisawa, I., Goto, T. and Tsuchizaki, T. (1980). Ann. Phytopath. Soc. Japan 46: 100 (Abstr. in Japanese).

3. Fujisawa, I., Goto, T., Tsuchizaki, T. and Iizuka, N. (1983). Ibid. 49: 299-307.

4. Hein, A. (1963). Mitt. Biol. Bundesanst. Land-Forstwirtsch. Berl. -Dahrlem. 108: 70-74 (Rev. 
Appl. Mycol. 43: 455. 1964).

5. Mink, G. I. and Uyeda, I. (1977). Plant Dis. Reptr. 61 : 398-401.

6. Paludan, N. (1964). Maanedsovers. Plantesygd. 407: 11-16. (Rev. Appl. Mycol. 43: 559. 1964).

7. Posnette, A. F. (1969). J. hort. Sci. $44: 403-406$.

8. Schade, C. (1969). NachrB1. dt. Pflschtzdienst. Berl., 23: 38-40 (Rev. Plant Pathol. 49 : 56. 1970).

9. Tsuchizaki, T. (1973). Ann. Phytopath. Soc. Japan 39: 67-72.

10. Uyeda, I. and Mink, G. I. (1981). Phytopathology 71: 1264- 1269.

和 文 摘 要

\section{アスパラガスから分離された Asparagus virus II \\ 藤澤一郎・後藤忠則・土崎常男・飯塚典男}

北海道内の外観健全なアスパラガスから検出される球形ウイルスの諸性質について調ベた。本ウイルスは 汁液接種を行った 12 科 43 種の植物のうち，ナス科，マメ科，アカザ科，ヒユ科の多くの植物に感染し，純化 ウイルスを接種したアスパラガスの若茎は，展開後まれにモザイクを生じた。本ウイルスはアスパラガス， タバコ，ヒャクニチソウ，ペチュニアで高率に種子伝染したが，アブラムシ伝染はしなかった。粗汁液中で の不活化温度は55〜60 C，希釈限界は1 $10^{-3} \sim 2 \times 10^{-4}$, 保存限界は $2 \sim 3$ 日（20 C）であった。

本ウイルスの純化標品中には直径 26〜36 nm の大きさの異なる 4 種類の球形粒子が観察された。純化ウイ ルスを用いて作製した抗血清の力価は 1/1024（重層法）で，寒天ゲル内で本ウイルスの純化標品拈よび感染 葉粗汁液と容易に反応した。また本ウイルスは Mink 博士より分譲された AVII-P 拉よび AVII-S の各抗 血清と明膫に反応し，AVII-P 抗血清と本抗血清との反応带の間には分枝線を形成した。以上の諸結果から 本ウイルスは既報の asparagus virus II のS系統に近いウイルスと同定した。

\section{Explanations for Plate}

Plate I. 1-4. Symptoms induced by asparagus virus II-J on various host.

1. Chenopodium quinoa, severe systemic mosaic and epinasty.

2. Nicotiana tabacum 'Xanthi nc', systemic mosaic with vein necrosis.

3. Gomphrena globosa, systemic mosaic with necrosis.

4. Asparagus officinalis, faint light-green mosaic.

5. Electron micrograph of purified asparagus virus II-J particles after sucrose density-gradient centrifugation. Bar represents $100 \mathrm{~nm}$

6a and 6b. Agar gel serological test with asparagus virus II-J. 6 a ; Center well contained asparagus virus $\mathrm{II}-\mathrm{J}(\mathrm{V})$. Wells, Up contained antiserum against asparagus virus II-P, and $\mathrm{Ja}, \mathrm{Jb}, \mathrm{Jc}$ contained antiserum against asparagus virus $\mathrm{II}-\mathrm{J}$ at dilutions up to $1 / 1,1 / 2$ and $1 / 4$, respectively. $6 \mathrm{~b}$; Wells contained purified asparagus virus $\mathrm{II}-\mathrm{J}(\mathrm{V})$, asparagus virus II- $\mathrm{J}$ antiserum (J) and asparagus virus II-S antiserum (Us). 
Plate I
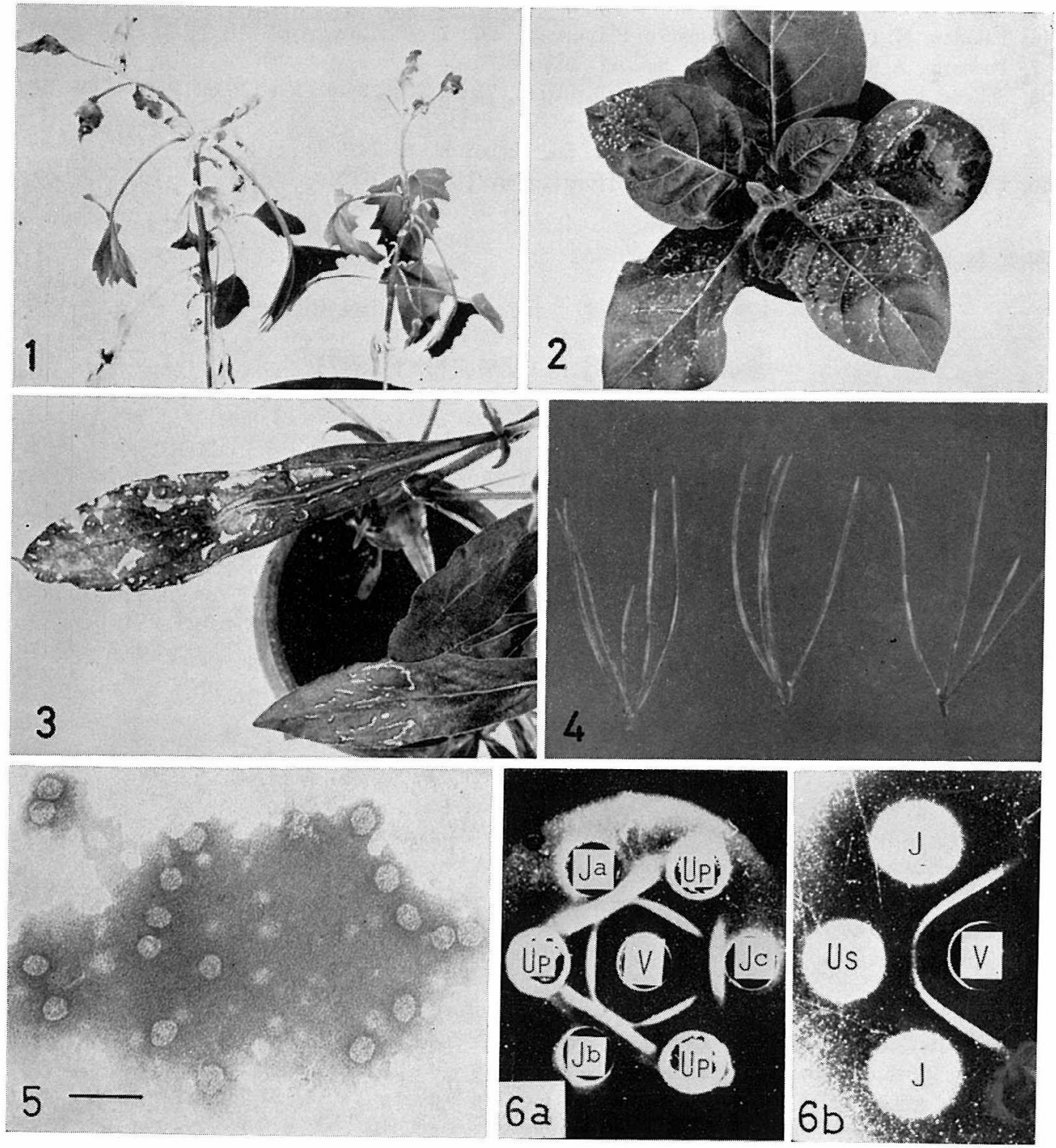